\title{
“ENDOTROPHIC" SPORULATION
}

\author{
S. H. Black* and Philipp Gerhardt \\ Department of Bacteriology, The University of Michigan, \\ Ann Arbor, Mich.
}

\section{Introduction}

The ability of vegetative cells to sporulate in water was first reported by Buchner (1890) and confirmed by Schreiber (1896) and Knaysi (1945). More recently, the replacement of a complex sporulation broth by water has proved to be a useful procedure for a variety of purposes (Grelet, 1951, 1955; Hardwick and Foster, 1952; Powell and Hunter, 1953; Foster and Perry, 1954; Perry and Foster, 1954, 1955; Murrell, 1955; Tinelli, 1955; Nakada, Matsushiro, and Miwatani, 1956; Ordal, 1957; McDonald and Wyss, 1959; Portellada, 1959a, $b$; Bennett and Williams, 1960; Black, Hashimoto, and Gerhardt, 1960; Hodson and Beck, 1960; Pelcher, 1961; Brock, 1962; Keynan, Murrell, and Halvorson, 1962; Stevenson, Miller, Strothman, and Slepecky, 1962).

Hardwick and Foster (1952) were among the first to exploit the "replacement technique" for a systematic study of sporogenesis and, as a result of their experiments, advanced the hypothesis that endospore development is strictly an endogenous process. Termed "endotrophic" sporulation, the metamorphosis of a vegetative cell to a spore in water was described as "occurring independently of exogenous nutrition and supported exclusively by the pre-existing makeup of the vegetative cell" (Foster and Perry, 1954).

Powell and Hunter (1953), however, observed a substantial degree of lysis after transfer of vegetative cells to water and contended that sporulation of the surviving cells took place not in water but in a dilute autolysate medium. Others employing the replacement technique (Murrell, 1955; Ordal, 1957; Pelcher, 1961) also have reported autolysis. In our experience with "endotrophic" sporulation (Black et al., 1960), we found that lysis of about 90 per cent of the population occurred when synchronously developing bacilli in the granular stage were removed from a primary culture, washed in water, and reincubated in water. We came to question, therefore, whether sporogenesis is in fact completely endogenous and whether autolysis in the population contributes to, or is required for, sporulation of the remaining cells. Using Bacillus cereus strain terminalis, we performed experiments designed to prevent lysis or interference by lytic products.

\section{Materials and Methods}

The test organism was grown either in baffled 2 liter Erlenmeyer flasks on a shaker or in carboy mass culture (Hashimoto, Black, and Gerhardt,

\footnotetext{
- Present address: Department of Microbiology, Baylor University College of Medi-
} cine, Houston, Texas. 
1960). Vegetative cells which had reached the granular stage in modified G-medium were centrifuged from the primary culture at $4^{\circ} \mathrm{C}$. under aseptic conditions and the cells washed twice by centrifugation in about 40 volume-equivalents of sterile distilled water. After an additional wash in either water or the test solution, the cells were resuspended to the original volume and transferred to appropriate secondary culture vessels.

A phase microscope, equipped with both light- and dark-contrast optics, was used for routine examination of the cultures. Dipicolinic acid (DPA) was analyzed by the method of Janssen, Lund, and Anderson (1957). Viable counts, before and after heating, were accomplished by making appropriate dilutions in 0.85 per cent $(w / v) \mathrm{NaCl}$ and spreading $0.1 \mathrm{ml}$. samples on trypticase-soy agar. Heat resistance was evaluated by exposing the cells, diluted tenfold in saline, at $80^{\circ} \mathrm{C}$. for 30 minutes.

\section{Results}

Attempts to prevent lysis. For these experiments, granular vegetative cells from the primary culture were washed twice in sterile distilled water and then washed once and resuspended not in water but in a possible stabilizing medium. Quantities of the suspension, $20 \mathrm{ml}$. were placed in $250 \mathrm{ml}$. Erlenmeyer flasks and incubated on a shaker for 24 hours at $30^{\circ} \mathrm{C}$.

The results summarized in TABLE 1 are from an experiment in which calcium chloride $(0.001$ per cent), maleate buffer $(p \mathrm{H} 7.0, M / 50)$, and polyethylene glycol (mol. wt. $4000,7.5$ per cent $w / v$ ) were compared as stabilizing media. It is notable that calcium alone was responsible for

\section{TABLE 1}

Alleviation of Cell Lysis during "Endotrophic" Sporulatron:

Calcium, Polyethylene Glycol, and Maleate Effects

\begin{tabular}{|c|c|c|c|c|c|c|}
\hline \multirow[b]{2}{*}{$\begin{array}{l}\text { Secondary sporulation } \\
\text { medium }\end{array}$} & \multicolumn{6}{|c|}{ Analysis 24 hours after transfer } \\
\hline & $\begin{array}{l}\text { Per cent } \\
\text { surviving } \\
\text { transferf }\end{array}$ & $\begin{array}{l}\text { Per cent } \\
\text { spores }\end{array}$ & $\begin{array}{c}\text { Viable } \\
\text { cells } / \mathrm{ml} . \\
\text { before } \\
\text { heating }\end{array}$ & $\begin{array}{l}\text { Viable } \\
\text { cells } / \text { ml. } \\
\text { after } \\
\text { heating }\end{array}$ & $\begin{array}{l}\text { Per cent } \\
\text { survival }\end{array}$ & $\begin{array}{c}\mu \mathrm{g} . \\
\mathrm{DPA} / \mathrm{mg} . \\
\text { dry spores }\end{array}$ \\
\hline G-medium control & $(100.0)$ & $>99$ & $9.2 \times 10^{8}$ & $4.7 \times 10^{8}$ & 51.0 & 64 \\
\hline Water & 13.0 & $>99$ & $1.2 \times 10^{8}$ & $2.9 \times 10^{8}$ & 2.4 & 14 \\
\hline $\mathrm{Cad}^{++}$ & 51.2 & $>99$ & $4.7 \times 10^{8}$ & $4.8 \times 10^{8}$ & 102.0 & 58 \\
\hline Maleate & 27.2 & $>99 \ddagger$ & $2.5 \times 10^{8}$ & $5.8 \times 10^{5}$ & 0.2 & 18 \\
\hline $\begin{array}{l}\text { Polyethylene glycol } \\
\text { (PEG) }\end{array}$ & 15.2 & $>99$ & $1.4 \times 10^{8}$ & $2.0 \times 10^{6}$ & 1.4 & 18 \\
\hline Maleate+PEG & 25.0 & $>99$ & $2.3 \times 10^{8}$ & $3.3 \times 10^{\circ}$ & 14.0 & 23 \\
\hline Maleate $+\mathrm{Ca}^{++}$ & 73.9 & $>99$ & $6.8 \times 10^{\mathrm{B}}$ & $3.8 \times 10^{8}$ & 56.0 & 77 \\
\hline $\mathrm{PEG}+\mathrm{Ca}^{++}$ & 57.6 & $>99$ & $5.3 \times 10^{8}$ & $4.6 \times 10^{8}$ & 87.0 & 58 \\
\hline Maleate + PEG $+\mathrm{Ca}^{++}$ & 63.0 & $>99$ & $5.8 \times 10^{8}$ & $3.9 \times 10^{8}$ & 67.0 & 88 \\
\hline
\end{tabular}

- Maleate buffer: $p \mathrm{H} \mathrm{7.0,M/50 \text {.Polyethyleneglycol(mol.wt.4000): } 7 . 5 \text { per cent }}$ $(w / v)$.

+ Based on the G-medium control as 100 per cent.

$\ddagger$ About 10 per cent were germinated. 
decreasing the amount of lysis from 87 per cent in water to 51 per cent. In addition, calcium raised the heat-survival percentage and the DPA content, as recorded previously (Black et al., 1960). Neither maleate buffer nor polyethylene glycol, alone or in combination, reduced the extent of lysis significantly. Yet when calcium was added to either, or to the combination, lysis was alleviated.

In TABLE 2 are the results of a companion experiment in which sucrose $(\mathrm{M} / 5)$ and phosphate buffer $(p \mathrm{H} 7.0, M / 30)$ were tested for their stabilizing capacity. Sucrose, in the absence of calcium, was inhibitory to sporulation. But a combination of sucrose, calcium, and phosphate or maleate buffer allowed nearly 70 per cent survival of the transferred cells, with the heat tolerance and DPA content of the resulting spores comparable to those formed in $G$-medium.

TABLE 2

Alleviation of Cell Lysis duRing "Endotrophic" Sporulation: Calcrum, Sucrose, Phosphate, and Maleate Effects

\begin{tabular}{|c|c|c|c|c|c|c|}
\hline \multirow[b]{2}{*}{$\begin{array}{l}\text { Secondary sporulation } \\
\text { medium }\end{array}$} & \multicolumn{6}{|c|}{ Analysis 24 hours after transfer } \\
\hline & $\begin{array}{l}\text { Per cent } \\
\text { surviving } \\
\text { transferf }\end{array}$ & $\begin{array}{l}\text { Per cent } \\
\text { spores }\end{array}$ & $\begin{array}{c}\text { Viable } \\
\text { cells /ml. } \\
\text { before } \\
\text { heating }\end{array}$ & $\begin{array}{c}\text { Viable } \\
\text { cells } / \mathrm{ml} \text {. } \\
\text { after } \\
\text { heating }\end{array}$ & $\begin{array}{l}\text { Per cent } \\
\text { survival }\end{array}$ & $\begin{array}{c}\mu \mathrm{g} . \\
\mathrm{DPA} / \mathrm{mg} . \\
\text { dry spores }\end{array}$ \\
\hline G-medium control & $(100.0)$ & $>99$ & $1.1 \times 10^{8}$ & $6.5 \times 10^{8}$ & 59.1 & 67 \\
\hline Water & 15.4 & $>99$ & $1.7 \times 10^{8}$ & $3.9 \times 10^{5}$ & 0.2 & 9 \\
\hline Sucrose & 8.5 & $<1$ & $9.4 \times 10^{7}$ & $<10^{5}$ & - & 3 \\
\hline $\mathrm{Ca}^{++}$ & 37.3 & $>99$ & $4.1 \times 10^{8}$ & $4.1 \times 10^{8}$ & 100.0 & $6 \mathrm{~J}$ \\
\hline Sucrose $+\mathrm{Ca}^{++}$ & 18.2 & 50 & $2.0 \times 10^{8}$ & $1.1 \times 10^{8}$ & 55.0 & 13 \\
\hline Sucrose $+\mathrm{PO}_{4} \equiv$ & 13.6 & $<1$ & $1.5 \times 10^{8}$ & $<10^{5}$ & - & 2 \\
\hline Sucrose + maleate & 23.6 & $>99 \neq$ & $2.6 \times 10^{8}$ & $<10^{5}$ & - & 11 \\
\hline Sucrose $+\mathrm{Ca}^{++}+\mathrm{PO}_{4} \equiv$ & 54.5 & $>99$ & $6.0 \times 10^{8}$ & $3.1 \times 10^{8}$ & 51.7 & 46 \\
\hline $\begin{array}{c}\text { Sucrose }+\mathrm{Ca}^{++}+ \\
\text {maleate }\end{array}$ & 65.4 & $>99$ & $7.2 \times 10^{8}$ & $4.7 \times 10^{8}$ & 65.3 & 68 \\
\hline
\end{tabular}

- Sucrose: $M / 5$. Phosphate buffer: $p H$ 7.0, $M / 30$. Maleate buffer: $p H$ 7.0, $M / 50$.

+ Based on the G-medium control as 100 per cent.

$\ddagger$ About 10 per cent were germinated. Most were normal in size but only partially refractile.

Attempts to eliminate interference by lytic products. Since the extent of survival after transfer could not be improved beyond about 70 per cent with the stabilizing media tried, it seemed possible that sporulation in water might be dependent on nutrilites released by the cells which lysed.

In an attempt to remove possible nutrient materials from the system, a distilled water suspension of washed, granular vegetative cells was placed in the upper section of a shaker-mounted dialysis flask (Gerhardt and Gallup, 1962). A membrane of Visking cellulose casing, with an average pore radius of $24 \AA$, separated the suspension from the lower section of the vessel, which was filled with water and through which water was circulated at a rate of $2 \mathrm{l} / \mathrm{hr}$. The dialysis vessel was incubated with shak- 
ing at $30^{\circ} \mathrm{C}$. for 24 hours. Included in the experiment was a typical Erlenmeyer flask secondary culture to which was added 0.1 per cent $(w / v)$ activated charcoal (Norite) as an absorbing material.

The results of this experiment, given in TABLE 3, show that the conditions provided for removal of lytic products, either by escape through the dialysis membrane or by absorption onto charcoal, were ineffective in preventing sporulation of the cells which did not lyse. It is not completely precluded, of course, that the nonlysing cells were able to take up nutrients before dialysis or absorption of lytic products occurred.

TABLE 3

Attempted Removal of Lytic Products durung Sporulation in Water

\begin{tabular}{|c|c|c|c|c|c|}
\hline \multirow[b]{2}{*}{$\begin{array}{l}\text { Secondary sporulation } \\
\text { medium }\end{array}$} & \multicolumn{5}{|c|}{ Analysis 24 hours after transfer } \\
\hline & $\begin{array}{l}\text { Per cent } \\
\text { surviving } \\
\text { transfer: }\end{array}$ & $\begin{array}{c}\text { Per cent } \\
\text { spores }\end{array}$ & $\begin{array}{c}\text { Viable } \\
\text { cells } / \mathrm{ml} \text {. } \\
\text { before } \\
\text { heating }\end{array}$ & $\begin{array}{c}\text { Viable } \\
\text { cells } / \mathrm{ml} \text {. } \\
\text { after } \\
\text { heating }\end{array}$ & $\begin{array}{l}\text { Per cent } \\
\text { survival }\end{array}$ \\
\hline G-medium control & $(100.0)$ & $>99$ & $8.4 \times 10^{8}$ & $5.4 \times 10^{8}$ & 64.0 \\
\hline Water control & 7.3 & $>99$ & $6.1 \times 10^{7}$ & $6.9 \times 10^{5}$ & 1.1 \\
\hline Water $+\mathrm{Ca}^{++}$control & 45.0 & $>99$ & $3.8 \times 10^{8}$ & $3.8 \times 10^{8}$ & 100.0 \\
\hline Watcr + dialysis $\uparrow$ & 1.6 & $>99$ & $1.3 \times 10^{7}$ & $3.7 \times 10^{8}$ & 28.0 \\
\hline Water+charcoal & 6.5 & 90 & $5.5 \times 10^{7}$ & $8.3 \times 10^{5}$ & 1.5 \\
\hline
\end{tabular}

- Based on the G-medum control as 100 per cent.

+ These values are corrected for the volume change which occurred during dialysis.

In further attempts to avoid contamination of the sporulation medium with the products of lysis, we sought to isolate single cells in water and to observe whether spores might then form. Impingement and washing of scattered cells on an ultrafilter was attempted first. Since cells in the granular stage tend to agglutinate (Hashimoto et al., 1960), granular cells from a primary culture were washed twice in sterile distilled water and subjected to sonic waves (Raytheon sonic oscillator, $10 \mathrm{kc}$./ $/ \mathrm{sec}$.) for $30 \mathrm{sec}-$ onds to disperse them. Appropriate dilutions of the dispersed cells were impinged on a Millipore filter so as to achieve wide spatial separation of the cells. Deionized water, which had been passed twice through a bacterial filter, was dropped onto and drawn through the Millipore filter at the rate of 1-2 drops/minute for about 24 hours. For observation of the cells, the pads were inverted and pressed lightly onto a thin layer of trypticase-soy agar on a microscope slide; the impression was covered with a slip and examined under phase-contrast optics.

Emulsification in oil of a water suspension was employed in a second approach. Granular cells were prepared as above, and an appropriate dilution was emulsified in mineral oil with the aid of a Vortex mixer. Drops of the emulsion were placed on microscope slides and covered with slips. After 24 hours' incubation, the specimens were examined, only those water droplets containing a single cell being scored. 
Under neither of the two experimental conditions did spores form: In the former situation the cells assumed many bizarre sizes and shapes, some with a cytoplasmic condensation resembling a forespore, but in none of the cells was there found a recognizable spore. In the latter situation the cells remained granular and without evidence of further maturation toward spores.

\section{Discussion}

Support for the notion that sporulation in water is an endogenous process was claimed by Hardwick and Foster (1952), who considered that synthesis of protein and nucleic acid during sporogenesis occurs de novo frow low molecular weight substances in an intracellular pool. This conclusion was based on experiments demonstrating that various amino acid and purine antimetabolite analogues inhibit sporulation and that their effects are reversed by the corresponding metabolites. Moreover, cells inhibited by the analogues showed no changes in their pools of amino acids, purines, or pyrimidines while uninhibited cells showed a fall in the pool levels as sporulation progressed. Inhibition by one analogue prevented utilization of all the amino acids, purines, and pyrimidines in the pool (Foster and Perry, 1954).

Several other workers (Nakada et al., 1956; Young and Fitz-James, 1959; Millet and Aubert, 1960) have shown that the level of free intracellular amino acids increases greatly just prior to sporulation but falls substantially during subsequent maturation. Other reserve materials apparently disappear also during sporulation: Hardwick and Foster (1952), having shown that certain enzyme activities are lost, suggested that enzymes break down with the products supplementing the pool. Foster and Perry (1954), using $S^{35}$-labeled cells, have given further evidence for protein degradation during sporogenesis. Tinelli (1955) has found that polysaccharides and beta-hydroxybutyric acid disappear from sporangia of Bacillus megaterium during sporulation. A stimulus for the catabolism of these endogenous materials may be the depletion of exogenous nutrients (Knaysi, 1945), but experimental proof for this idea is lacking.

Objection to the concept of "endotrophic" sporulation was first posed by Powell and Hunter (1953). They suggested that lysis of 80 to 90 per cent of the transferred cells converted the water to a dilute nutrient medium, which supported the sporulation of surviving cells. Such lysis has been observed repeatedly (Murrell, 1955; Ordal, 1957; Black et al., 1960; Pelcher, 1961). Occasionally, however, sporulation does take place in the seeming absence of lysis (Perry and Foster, 1954; Portellada, 1959a).

Recently, Young and Fitz-James (1959) have raised another objection to the notion that sporulation is altogether endogenous. They contend that the levels of calcium (Powell and Strange, 1956) and cysteine (Vinter, 1959 ) in spores, greater than those in their progenitor cells, "could not be derived in such magnitude entirely from intracellular constituents." Further, the incorporation of nutrients from the medium into a maturing spore (Young and Fitz-James, 1959), the increase in dry weight during 
sporogenesis (Young and Fitz-James, 1959), and the depletion of carbonand nitrogen-containing compounds in sporulation media (Powell and Strange, 1956) were thought to indicate that "during normal sporulation exogenous nutrition is utilized if not required for the formation of refractile spores."

In fact, spores formed in water are not normal but are morphologically defective, relatively susceptible to heat, and low in DPA and calcium (Portellada, 1959b; Black et al., 1960; Pelcher, 1961; Keynan et al., 1962). These defects can be prevented by adding calcium, or strontium, to the watery menstruum early in sporogenesis (Black et al., 1960; Pelcher, 1961). The conclusion seems inescapable, therefore, that at least calcium must be supplied exogenously for the formation of normal spores. In this sense, sporogenesis cannot be said to be completely endogenous; but within the framework of organic metabolism, it could be.

Question remains, moreover, whether autolysis contributes to waterformed spores, normal or abnormal. Our attempts to resolve the problem have not, to date, been definitive. Although lysis of the secondary suspension could be alleviated by adding calcium alone or with sucrose and maleate buffer, the effect at best was incomplete. Although spores were formed in a dialyzed or absorbed suspension of cells, there is reasonable doubt about the efficiency of lytic product removal by these procedures. And although spores were not formed when separated from lytic contamination by isolation on a filter or in microdroplets, it might be said that, respectively, intracellular reserves were leached away also and that the oxygen needed for utilization of endogenous materials may have been limiting. Altogether, the results must be taken as preliminary. They help to define the conditions limiting the replacement technique, but they do not resolve the question of whether sporulation is completely "endotrophic."

\section{Acknowledgments}

The technical assistance of Sara S. DeLong is acknowledged appreciatively. The research was supported in part by a contract from the Office of Naval Research, Department of the Navy, and Grant E-619-C8 from the National Institutes of Health, U. S. Public Health Service.

\section{References}

Bennett, E. O.\& R. P. Williams. 1960. Nucleic acid phosphorus content of Bacillus anthracis and Bacillus cereus. II. The nucleic acid phosphorus content of spores. Jap. J. Microbiol. 4: 157-162.

Black, S. H., T. Hashimoto \& P. Gerhardt. 1960. Calcium reversal of the heat susceptibility and dipicolinate deficiency of spores formed "endotrophically" in water. Can. J. Microbiol. 6: 213-224.

Brock, T. D. 1962. Inhibition of endotrophic sporulation by antibiotics. Nature. 195: 309.

BuchNer, H. 1890. Uber die Ursache der Sporenbildung beim Milzbrandbacillus. Zentr. Bacteriol. Parasitenk. 8: 1-6. 
Foster, J. W. \& J. J. Perry. 1954. Intracellular events occurring during endotrophic sporulation in Bacillus mycoides. J. Bacteriol. 67: 295-302.

Gerhardt, P. \& D. M. Gallup. 1962. Mass cell production by dialysis fermentation process. Abstract. VIII Internat. Cong. Microbiol. P. 69.

Grelet, N. 1951. Le déterminisme de la sporulation de Bacillus megatherium. I. L'effet de l'épuisement de l'aliment carboné en milieu synthétique. Ann. Instit. Pasteur. 81: 430-439.

Grelet, N. 1955. Nutrition azotée et sporulation de Bacillus cereus var. mycoides. Ann. Instit. Pasteur. 88: 60-75.

Hardwick, W. A. \& J. W. Foster. 1952. On the nature of sporogenesis in some aerobic bacteria. J. Gen. Physiol. 35: 907-927.

Hashimoto, T., S. H. Black \& P. Gerhardt. 1960. Development of fine structure, thermostability, and dipicolinate during sporogenesis in a Bacillus. Can. J. Microbiol. 6: 203-212.

Honson, P. H. \& J. V. BECK. 1960. Origin of deoxyribonucleic acid of the bacterial endospore. J. Bacteriol. 79: 661-665.

Janssen, F. W., A. J. Lund \& L. E. Anderson. 1957. Colorimetric assay for dipicolinic acid in bacterial spores. Science. 127: 26-27.

Keynan, A., W. G. Murrell \& H. O. Halvorson. 1962. Germination properties of spores with low dipicolinic acid content. J. Bacteriol. 83: 395-399.

KNAYsi, G. 1945. A study of some environmental factors which control endospore formation by a strain of Bacillus mycoides. J. Bacteriol. 49: 473-493.

McDonald, W. C. \& O. Wyss. 1959. Mutagenic response during sporulation of Bacillus cereus. Radiation Research. 11: 409-417.

Mil.tet, J. \& J.-P. Aubert. 1960. Le métabolisme de l'acide glutamique au cours de la sporulation chez Bacillus megaterium. Ann. Instit. Pasteur. 98: 282-290.

MurRel., W. G. 1955. In The Bacterial Endospore. University of Sydney. Sydney, Australia.

Nakada, D., A. Matsushmo \& M. Mrwatani. 1956. Studies on the development of aerobic sporeforming bacteria. I. Incorporation of amino acids in the development of Bacillus cereus. Med. J. Osaka Univ. 6: 1047-1060.

ORDAL, Z. J. 1957. The effect of nutritional and environmental conditions of sporulation. In Spores. H. O. Halvorson, Ed, Am. Instit. Biol, Sci. Washington, D. C.

Pelcher, E. A. 1961. Some characteristics of spores of Bacillus cereus produced by a replacement technique. M.S. Thesis. University of Illinois. Urbana, Illinois.

Perry, J. J. \& J. W. Foster. 1954. Non-involvement of lysis during sporulation of Bacillus mycoides in distilled water. J. Gen. Physiol. 37: 401-409.

Perry, J. J. \& J. W. Foster. 1955. Studies on the biosynthesis of dipicolinic acid in spores of Bacillus cereus var. mycoides. J. Bacteriol. 69: 337-346.

Portellada, P. C. L. 1959a. Estudos sôbre esporogênese. II. Formação de esporos endotróficos. Anais de Microbiol. 7: 71-76.

Portellada, P. C. L. 1959b. Estudos sôbre esporogênese. III. Acido dipicolínico e formação de esporos. Anais de Microbiol. 7: 77-84.

Powell, J. F. \& J. R. Hunter. 1953. Sporulation in distilled water. J. Gen. Physiol. 36: 601-606.

Powell, J. F. \& R. E. Strange. 1956. Biochemical changes occurring during sporulation in Bacillus species. Biochem. J. 63: 661-668.

SCHREIBER, O. 1896. Über die physiologischen Bedingungen der endogenen Sporenbildung bei Bacillus anthracis, subtilis, und tumescens. Zentr. Bakteriol. Parasitenk. 20 (Abt. 1) : 353-374. 
Stevenson, J., K. Mrller, R. Strothman \& R. A. Slepecky. 1962. Occurrence and function of poly-beta-hydroxybutyric acid in various Bacillus species. Bacteriol. Proc. P. 47.

Tinellr, R. 1955. Etude de la biochimie de la sporulation chez Bacillus megaterium. II. Modifications biochimique et échanges gazeux accompagnant la sporulation provoquée par carence de glucose. Ann. Instit. Pasteur. 88; 364-375.

VINTER, V. 1959. Differences in cysteine content between vegetative cells and spores of Bacillus cereus and Bacillus megaterium. Nature. 183: 998-999.

Young, I. E. \& P. C. Frtz-James. 1959. Chemical and morphological studies of bacterial spore formation. II. Spore and parasporal protein formation in Bacillus cereus var. alesti. J. Biophys. Biochem. Cytol. 6: 483-498. 